\title{
PERTIMBANGAN HAKIM TERHADAP PENYALAHGUNAAN NARKOTIKA PADA
} ANAK-ANAK

\author{
Dra. Deliani, SH, M.Hum \\ Universitas Amir Hamzah \\ deliani@gmail.com
}

\begin{abstract}
Abstrak
Narkotika dan psikotropika merupakan obat atau bahan yang bermanfaat di bidang pengobatan, pelayanan kesehatan, dan pengembangan ilmu pengetahuan, dan pada sisi lain dapat menimbulkan ketergantungan yang sangat merugikan apabila dipergunakan tanpa pengendalian, pengawasan yang ketat dan seksama. Zat-zat narkotika yang semula ditunjukkan untuk kepentingan pengobatan, namun dengan perkembangan ilmu pengetahuan dan teknologi, jenis-jenis narkotika dapat diolah sedemikian banyak serta dapat pula disalahgunakan fungsinya. Anak adalah bagian dari generasi muda yang merupakan potensi dan penerus cita-cita perujuangan bangsa di masa yang akan datang. Anak membutuhkan pembinaan dan perlindungan khusus dalam menjamin pertumbuhan dan perkembangan fisik, mental dan sosial secara seimbang. Sungguh ironis bahwa seorang anak yang seharusnya bermain dan belajar harus menghadapi masalah hukum dan menjalani proses peradilan yang hampir sama prosesnya dengan orang dewasa. Tentu saja hal ini menimbulkan pro kontra. Di satu sisi banyak pihak yang menganggap menjatuhan pidana bagi anak adalah tidak bijak, namun ada sebagian yang beranggapan pemidanaan terhadap anak penting dilakukan agar sikap buruk anak tidak terjadi sampai dewasa, artinya agar memberi efek jera bagi si anak. Penyalahgunaan narkotika tak lagi memandang usia, mulai dari anak-anak, remaja, orang dewasa hingga orang tua sekalipun tak luput dari jeratan penyalahgunaan narkotika ini. Diperkirakan sekitar 1,5 persen dari total penduduk Indonesia adalah korban dari penyalahgunaan narkotika tersebut. Masalah peredaran narkotika ini juga tak kalah mengkhawatirkan,karena tidak hanya terjadi di kota-kota besar saja juga merambah ke pelosok Indonesia.
\end{abstract}

\section{Kata kunci : Pertimbangan Hakim, Penyalahgunaan Narkotika}




\section{PENDAHULUAN}

Dengan populasi penduduk yang sangat besar, melebihi angka 200 juta, Indonesia merupakan pasar potensial bagi peredaran gelap narkotika. Pada awalnya Indonesia hanya sebagai tempat persinggahan lalu lintas perdagangan narkotika, dikarenakan lokasinya yang strategis. Lambat laun para pengedar gelapnarkotika ini mulai menjadikan Indonesia sebagai pasar incaran untuk mengedarkan narkotika. Seiring berjalanannya waktu Indonesia mulaibertransformasi, tidak hanya sebagai tempat peredaran narkotika namun juga sudah menjadi tempat menghasilkan narkotika. Hal ini terbukti dengan ditemukannya beberapa laboratorium narkotika di wilayah Indonesia. Pada hakekatnya, segala bentuk penanganan terhadap anak yang menghadapi masalah hukum dalam hal ini menghadapai masalah mengedarkan narkotika harus dilakukan dengan memprioritaskan kepentingan terbaik untuk si anak. Oleh karena itu keputusan yang diambil dalam kasus tersebut harus adil dan proposional tidak semata- mata dilakukan atas pertimbangan hukum tapi juga mempertimbangkan faktor lain seperti kondisi lingkungan sekitar, status sosial anak, dan keadaan keluarga. Pembicaraan tentang anak dan perlindungannya tidak akan pernah berhenti sepanjang sejarah kehidupan, karena anak adalah generasi penerus bangsa dan penerus pembangunan, yaitu generasi penerus yang dipersiapkan sebagai subyek pelaksana pembangunan yang berkelanjutan dan pemegang kendali masa depan suatu negara, tidak terkecuali Indonesia. Perlindungaan anak Indonesia berarti melindungi potensi sumber daya insani dan membangun manusia seutuhnya, menuju masyarakat yang adil dan makmur, materiil spiritual berdasarkan Pancasila dan UUD 1945. Dari pembicaraan tentang anak dan perlindungan inilah kita sering dihadapkan adanya penyimpangan perilaku di kalangan anak. Bahkan terdapat anak yang melakukan perbuatan melanggar hukum, salah satunya adalah penyalahgunaan narkotika. Dalam perkembangan masyarakat belakangan ini terdapat beberapa hal yang kian mendorong akselerasi merajalelanya organisasiorganisasi kejahatan atau sindikat peredaran narkotika tersebut untuk memperluas jaringan dan bergerakAnak terlibat dalam penyalahgunaan narkotika tentunya 
tidak lahir dengan tiba-tiba, melainkan melalui proses pertimbangan dari organisasi-organisasi kejahatan atau sindikat peredaran narkotika, dimana kejahatan tersebut memang menjanjikan keuntungan yang cukup menggiurkan. Dalam perkembangan masyarakat belakangan ini terdapat beberapa hal yang kian mendorong akselerasi merajalelanya organisasi-organisasi kejahatan atau sindikat peredaran narkotika tersebut untuk memperluas jaringan dan bergerak.melintasi negara atau bersifat internasional, utamanya yang menyangkut adanya kemajuan teknologi komunikasi dan transportasi sehingga memudahkan mobilitas manusia keseluruhan dunia, di samping itu, karena keuntungan yang menjanjikan tersebut berpengaruh terhadap upaya organisasi-organisasi kejahatan atau sindikat peredaran narkotika untuk memasuki ke semua wilayah dunia

\section{KAJIAN PUSTAKA}

Narkotika adalah zat atau obat yang berasal dari tanaman atau bukan tanaman, baik sintesis maupun semi sintesis yang dapat menyebabkan penurunan atau perubahan kesadaran, hilangnya rasa, mengurangi sampai menghilangkan rasa nyeri, dan dapat menimbulkan ketergantungan, yang dibedakan ke dalam golongan-golongan sebagaimana terlampir dalam undang-undang ini atau yang kemudian ditetapkan dengan Keputusan Menteri Kesehatan. Penyalahgunaan penggunaan narkotika oleh seseorang dapat menjadikan orang tersebut tergantung (adictie) pada narkotika. Ketergantungan seseorang terhadap narkotika dapat ringan dan dapat pula berat. Berat-ringannya ketergantungan itu bisa diukur dari kenyataan sampai seberapa jauh seseorang bisa melepaskan diri dari penggunaan narkotika itu. Salah satu akibat yang ditimbulkan oleh penggunaan narkotika adalah timbulnya suatu keadaan di mana si pemakainya menjadi lupa atau tidak sadarkan diri di bawah pengaruh narkotika, sehingga seseorang dapat melepaskan diri situasi konflik. Seseorang akan melarikan diri dari situasi yang tidak dapat diatasinya. Akan tetapi sebab dari kesulitan itu sama sekali tidak dapat dihilangkan 


\section{DISCUSSION}

\section{Penyebaran Narkotika di Indonesia}

Hingga kini penyebaran narkoba sudah hampir tak bisa dicegah, dengan maraknya narkotika dan obat-obatan terlarang telah banyak mempengaruhi mental, sekaligus pendidikan bagi para pelajar saat ini. Masa depan bangsa yang besar ini bergantung sepenuhnya pada upaya pembebasan kaum muda dari bahaya narkoba. Narkotika telah menyentuh lingkaran yang semakin dekat dengan kita semua. Teman dan saudara kita mulai terjerat oleh narkoba yang sering kali dapat mematikan.Di Indonesia, perkembangan pencandu narkoba semakin pesat. Para pencandu narkotika itu pada umumnya berusia antara 11 sampai 24 tahun. Artinya usia tersebut ialah usia produktif atau usia pelajar. Karena kebiasaan merokok ini sepertinya sudah menjadi hal yang wajar di kalangan pelajar saat ini. Dari kebiasaan inilah, pergaulan terus meningkat, apalagi ketika pelajar tersebut bergabung ke dalam lingkungan orang-orang yang sudah menjadi pencandu narkoba. Awalnya mencoba, lalu kemudian mengalami ketergantungan.

\section{Bahaya Narkotika Bagi Penggunanya}

Penyalahgunaan narkotika di kalangan generasi muda kian meningkat, maraknya penyimpangan perilaku tersebut dapat membahaykan kehidupan bangsa di kemudian hari, karena pemuda sebagai generasi yang diharapkan menjadi penerus bangsa. Semakin hari generasi muda yang mengkonsumsi narkoba semakin rapuh karena di gerogoti narkoba dan zat - zat adiktif yang menghancurkan syaraf sehingga generasi muda tidak dapat berpikir jernih.

Bagaimana pemuda akan menjadi generasi penerus bangsa jika bila mengurus diri sendiri sudah tidak bisa. Akibatnya generasi harapan penerus bangsa yang tangguh dan cerdas hanya akan tinggal harapan. Penyalahgunaan obat jenis narkoba sangat berbahaya karena dapat mempengaruhi susunan syaraf, mengakibatkan ketagihan, dan ketergantungan, karena mempengaruhi susunan syaraf. Narkotika menimbulkan perubahan perilaku, perasaan, persepsi,dan 
kesadaran. Pemakaian narkoba secara umum dan psikotropika yang tidak sesuai dengan aturan dapat menimbulkan efek yang membahayakan tubuh. Beberapa dampak penggunaan narkotika adalah sebagai berikut :

1. Depresan, yaitu menekan sistem syaraf pusat dan mengurangi aktifitas fungsional tubuh sehingga pemakai merasa tenang, bahkan bisa membuat pemakai tidur dan tak sadarkan diri. Bila kelebihan dosis bisa mengakibatkan kematian. Jenis narkotika depresan antara lain opioda, dan berbagai turunannya seperti morphin dan heroin. Contoh yang populer sekarang adalah Putaw.

2. Stimulan, merangsang fungsi tubuh dan meningkatkan kegairahan serta kesadaran. Jenis stimulan: kafein, kokain, amphetamin. Contoh yang sekarang sering dipakai adalah shabu-shabu dan ekstasi.

3. Halusinogen, efek utamanya adalah mengubah daya persepsi atau mengakibatkan halusinasi. Halusinogen kebanyakan berasal dari tanaman seperti mescaline dari kaktus dan psilocybin dari jamur-jamuran. Selain itu ada jugayang diramu di laboratorium seperti LSD. Yang paling banyak dipakai adalah marijuana atau ganja.

\section{Upaya Pencegahan dan Penanggulangan Bahaya Narkotika}

Upaya pencegahan penyebaran narkoba di kalangan generasi muda sudah seharusnya menjadi tanggung jawab bersama, dalam hal ini semua pihak termasuk orang tua, guru, dan masyarakat harus turut berperan aktif dalam mewaspadai ancaman dari narkotika.

Adapun upaya - upaya lebih kongkret yang dapat dilakukan adalah melakukan kerja sama dengan pihak yang berwenang untuk melakukan penyuluhan tentang bahaya narkotika, atau mungkin mengadakan razia mendadak secara rutin.Kemudian pendampingan dari orang tua siswa itu sendiri dengan memberikan perhatian dan kasih sayang.Pihak sekolah harus melakukan pengawasan yang ketat terhadap gerak-gerik anak didiknya, karena biasanya penyebaran (transaksi) narkotika sering terjadi di sekitar lingkungan 
sekolah.Yang tak kalah penting adalah, pendidikan moral dan keagamaan harus lebih ditekankan kepada siswa. Karena salah satu penyebab terjerumusnya anak - anak ke dalam jerat narkotika ini adalah kurangnya pendidikan moral dan keagamaan yang mereka pelajari dan mereka serap, sehingga perbuatan tercela seperti ini pun, akhirnya mereka lakukan.

\section{KESIMPULAN}

\section{Kesimpulan}

1. Masih banyak lagi upaya yang bisa dilakukan untuk mencegah generasi muda memakai narkoba. dan untuk mencapainya harus ada kekompakan antara individu, keluarga, sekolah, dan masyarakat sekitar. Yang semuanya memiliki peran penting dalam upaya pencegahan dan penanggulangan narkotika.

2. Pendekatan penanggulangan penyalahgunaan narkoba di Indonesia saat ini belum benar-benar terpadu dan terlihat setiap instansi atau kelompok masyarakat bekerja sendiri-sendiri sehingga hasil yang diperoleh belum optimal. Sebenarnya banyak instansi selain Polri yang memiliki tugas memberantas penyalahgunaan Narkotika. Belum ada upaya pembinaan khusus terhadap pengguna sebagai korban, karena masih beranggapan bahwa para pengguna itu adalah penjahat dan tanpa mendalami lebih jauh mengapa mereka sampai mengkonsumsi atau menyalahgunakan Narkotika.

\section{Saran}

1. Peran serta masyarakat sangat rendah karena mereka masih berpandangan bahwa pemberantasan penyalahgunaan Narkotika adalah tugas dan tanggung jawab polisi. Dengan demikian mereka kurang peduli dan kurang berpartisipasi aktif dalam upaya penanggulangan penyalahgunaan narkotika.

2. Sebaiknya selalu dilakukan penyuluhan atau komunikasi, informasi dan 
edukasi kepada masyarakat lebih banyak menunggu jika ada permintaan dari pihak lain (kelompok masyarakat)

\section{REFERENCES}

Apandi, Yusuf. 2010. Katakan Tidak Pada Narkoba. Jakarta : Simbiosa Rekatama Media.

Arikunto, Suharsimi. 2016. Prosedur Penelitian Suatu Pendekatan Praktik Edisi Revisi. Jakarta: Rineka Cipta.

Bambang Waluyo, 2016, Penelitian Hukum Dalam Praktek, Jakarta: Sinar Grafika

Bagir Manan.2012. (dalam buku Gatot Supramono), Hukum Acara Pengadilan Anak, Jakarta, Djambatan

Dadang Hawari,2014.Al-Qur'an: Ilmu Kedokteran Jiwa dan Kesehatan Jiwa (Jakarta: PT. Dana Bhakti Prima Yasa, )

Nashriana, 2011, Perlindungan Hukum Pidana bagi Anak di Indonesia., Ed 1-1. Jakarta: Rajawali Pers

Muhammad Yamin , 2012, Tindak Pidana Khusus, Cetakan Pertama. Bandung: Pustaka Setia

Moh. Makaro Taufik, Suhasril, dan Moh. Zakky, 2015, Tindak Pidana Narkotika, Cetakan Kedua.Bogor: Ghalia Indonesia

Mohammad Taufik Makarao, Wenny Bukamo, dan Syaiful Azri, 2013, Hukum Perlindungan Anak dan Penghapusan Kekerasan dalam Rumah Tangga, Jakarta: Rineka Cipta

Koesno Adi, 2014, Diversi Tindak Pidana Narkotika Anak, Malang: Setara Prees. 